\title{
Assessment of Organochlorine Pesticides in Water, Sediment, African Cat fish and Nile tilapia, Consumer Exposure and Human Health Implications, Volta Lake, Ghana
}

\author{
Gustav Gbeddy ${ }^{1 *}$, Eric Glover ${ }^{1,2}$, Israel Doyi ${ }^{1}$, Samuel Frimpong $^{3}$ and Louis Doamekpor ${ }^{4}$ \\ ${ }^{1}$ National Radioactive Waste Management Centre, Ghana Atomic Energy Commission (GAEC), Atomic, Ghana \\ ${ }^{2}$ Graduate School of Nuclear and Allied Sciences, University of Ghana, Atomic Campus, Ghana \\ ${ }^{3}$ Ghana Standards Authority, Testing Division, Pesticide Residue Laboratory, Accra, Ghana \\ ${ }^{4}$ Chemistry Department, University of Ghana, Legon, Ghana
}

\begin{abstract}
The levels of organochlorine pesticides (OCPs) in water, sediment, Nile Tilapia and African Catfishes were assessed to estimate possible consumer exposures and potential health implications from the Volta Lake, Ghana using gas chromatography equipped with ${ }^{63} \mathrm{Ni}$ electron-capture detector. In agreement with their lipophilic nature, higher levels of OCPs were measured in fish samples than water and sediment samples. Heptachlor was the highest level of OCP measured with concentration of $37.75 \mathrm{ng} / \mathrm{g}$ in tilapia gill followed by $\delta-\mathrm{HCH}$ in tilapia muscle and catfish muscle respectively. All OCP residues in tilapia muscle and catfish muscle did not differ significantly $(p<0.05)$. The highest total OCP load of $66.70 \mathrm{ng} / \mathrm{g}$ was measured in tilapia muscle, followed by $63.44 \mathrm{ng} / \mathrm{g}$ for tilapia gill. This observation however, contradicts the lipophilic nature of OCPs since the fat content of tilapia gill (14.49\%) was five times that of muscle tissues $(2.80 \%)$. Gill tissues however, may be serving as channels to absorb and distribute OCPs to various fatty tissues in the anatomy and physiology of fish. In water a sample $\delta-\mathrm{HCH}$ was the highest OCP determined with concentration of $0.669 \mu \mathrm{g} / \mathrm{L}$. DDT was not detected in both water and sediment samples but was however measured in fish samples. This could be attributed to historical use since DDD and DDE were measured in higher concentrations. From the consumer exposure analysis, the water from the lake is relatively safe for domestic, agricultural and ranching since the acute risk ratio for all detected OCP residues were less than one. The Nile tilapia and African catfishes from this lake are also comparatively safe for human consumption because the estimated dietary intakes from this study are far below the corresponding acceptable dietary intakes for various OCPs. This study therefore shows a declining trend on the environmental burden of OCPs in the middle section of the Volta Lake.
\end{abstract}

Keywords: Organochlorine pesticides; Consumer exposure; Health implications; Acute risk ratio; Estimated dietary intakes; Acceptable dietary intakes

\section{Introduction}

The World Health Organisation (WHO) says pesticide poisoning is the probable cause of 18 mysterious deaths in south-western Nigeria [1]. This statement has simply re-echoed the observations made several decades ago by a renowned environmental biologist Rachel Carson.

For the first time in the history of the world, every human being is now subjected to contact with dangerous chemicals, from the moment of conception until death. In less than two decades of their use, synthetic pesticides have been so thoroughly distributed throughout the animate and inanimate world that they occur virtually everywhere. They have been recovered from most of the major river systems. Residues of these chemicals linger in soil to which they may have been applied a dozen years before. They have entered and lodged in the bodies of fish, birds, reptiles, domestic and wild animals so universally that scientists carrying on animal experiments find it almost impossible to locate subjects free from such contamination. They have been found in fish in remote mountain lakes, in earthworms burrowing in soil, in the eggs of birds and in man himself. For these chemicals are now stored in the bodies of the vast majority of human beings, regardless of age [2].

Organochlorine pesticides (OCPs) have been widely used in the past but due to their environmental persistence, and accumulation in the food chain, they can still pose problems for human health [3]; they are among the major types of pesticides notorious for their high toxicity [4]. Biological samples (fish, aquatic and terrestrial mammals and birds) as well as soils and sediments have higher concentrations of most OCPs than water or air, making them more suitable for routine monitoring and more relevant in the context of exposure of humans and wildlife [5]. Fish accumulates some organic chemicals particularly OCPs in its fatty tissues due to its inability to metabolize them in the food they eat and from the intake of particulates in water and sediment unto which these chemicals have been adsorbed [6]. The region of accumulation of pesticides within fish varies with the route of uptake. The gills are directly in contact with water. Therefore, the concentration of pesticides in gills reflects their concentration in water where the fish live [7]. The average concentration of these OCPs increases dramatically across a food chain. The bioaccumulation of organochlorines in fish and other animals is the reason why most of the human daily intake of such chemicals comes from our food supply rather than from water [6]. Their potential use as bio-monitors is therefore significant in the assessment of bioaccumulation and biomagnifications of contaminants within the ecosystem [7]. It has been

*Corresponding author: Gustav Gbeddy, National Radioactive Waste Management Centre, Ghana Atomic Energy Commission (GAEC), Atomic, Ghana; Tel: 233-261626-558; E-mail: ggbeddy@gmail.com

Received May 11, 2015; Accepted May 25, 2015; Published May 31, 2015

Citation: Gbeddy G, Glover E, Doyi I, Frimpong S, Doamekpor L (2015) Assessment of Organochlorine Pesticides in Water, Sediment, African Cat fish and Nile tilapia Consumer Exposure and Human Health Implications, Volta Lake, Ghana. J Environ Anal Toxicol 5: 297. doi:10.4172/2161-0525.1000297

Copyright: $\odot 2015$ Gbeddy G, et al. This is an open-access article distributed under the terms of the Creative Commons Attribution License, which permits unrestricted use, distribution, and reproduction in any medium, provided the original author and source are credited. 
Citation: Gbeddy G, Glover E, Doyi I, Frimpong S, Doamekpor L (2015) Assessment of Organochlorine Pesticides in Water, Sediment, African Cat fish and Nile tilapia, Consumer Exposure and Human Health Implications, Volta Lake, Ghana. J Environ Anal Toxicol 5: 297. doi:10.4172/21610525.1000297

Page 2 of 8

found that greater than $80 \%$ of the total intake of pesticide residues in human beings is through the food chain $[8,9]$.

OCPs have been used in Ghana for over 40 years, both for agricultural and public health purposes, with their residues been detected in water, sediments, vegetable crops, fish and in humans [10]. Although the production and use of many types of OCPs have been severely limited in many countries including Ghana, they are nevertheless still being used unofficially in large quantities in many parts of Ghana [11], and in other developing countries because of their effectiveness as pesticides and their relatively low cost [12] as well as inadequate regulation and management on the production, trade and use of these chemicals [13].

Volta Lake is one of the largest man-made lakes in the world as well as the most important inland water resource in Ghana of which Kpando Torkor Lake forms an integral portion. It originates from Burkina Faso, Côte d'Ivoire and Togo, flows through farming regions in these countries, and then through Ghana into the Gulf of Guinea. Organochlorine compounds (e.g. lindane, endosulfan) were used in these regions. The lake also experiences bad fishing practices, including the use of explosives and chemicals. The short distances between agricultural fields and water-ways also increase the probability of agrochemicals reaching waterways via agricultural run-off. The presence of such foreign chemicals in the lake, including pesticides, could readily cause detrimental impacts on the lake's water quality and also adversely affect the vital fish population [11].

The main objective of this study is to evaluate the organochlorine pesticide residues in water, sediment, African Catfish and Nile tilapia from the Volta Lake; evaluate the suitability of the water and fish for continuous human consumption.

\section{Materials and Methods}

\section{Sampling}

Kpando Torkor is located about $8 \mathrm{~km}$ south west of Kpando, the municipal capital. Torkor Lake constitutes a vital portion of the Volta River on longitude $0^{\circ} 7$ and latitude $6^{\circ} 58^{\prime}$ (Figure 1).

Lake water, unlike river water, is not uniform in that the resident time is very high and the turnover rate of substances is very low. Thus, no single sample can be taken to be representative of the lake. Seven sampling stations were therefore, chosen randomly for both sediment and water sampling. At each sampling station, three each of water and bottom sediment samples were collected. Water samples were collected directly into a pre-cleaned, dried $740 \mathrm{~mL}$ glass bottles fitted with a screw cap lined with clean dry aluminium foil whilst bottom sediments were collected into a pre-cleaned aluminium foil by the help of a diver with the aid of pre-cleaned glass bottles.

Nile tilapia and catfish samples were purchased directly from fishermen at the landing site. The scales and internal organs were removed since this was the usual practice by traders in the study area. This particular species were selected based on their availability as well as their commercial value. The fish samples were wrapped in a precleaned aluminium foil and then packaged into zip lock plastic bags.

On each sampling trip, twenty one samples each of water, sediment and fish were collected totaling 84 samples. The total number of samples collected for analysis was 168 . All samples collected were stored immediately in an ice chest at $4^{\circ} \mathrm{C}$ and then transported to the laboratory for analysis.

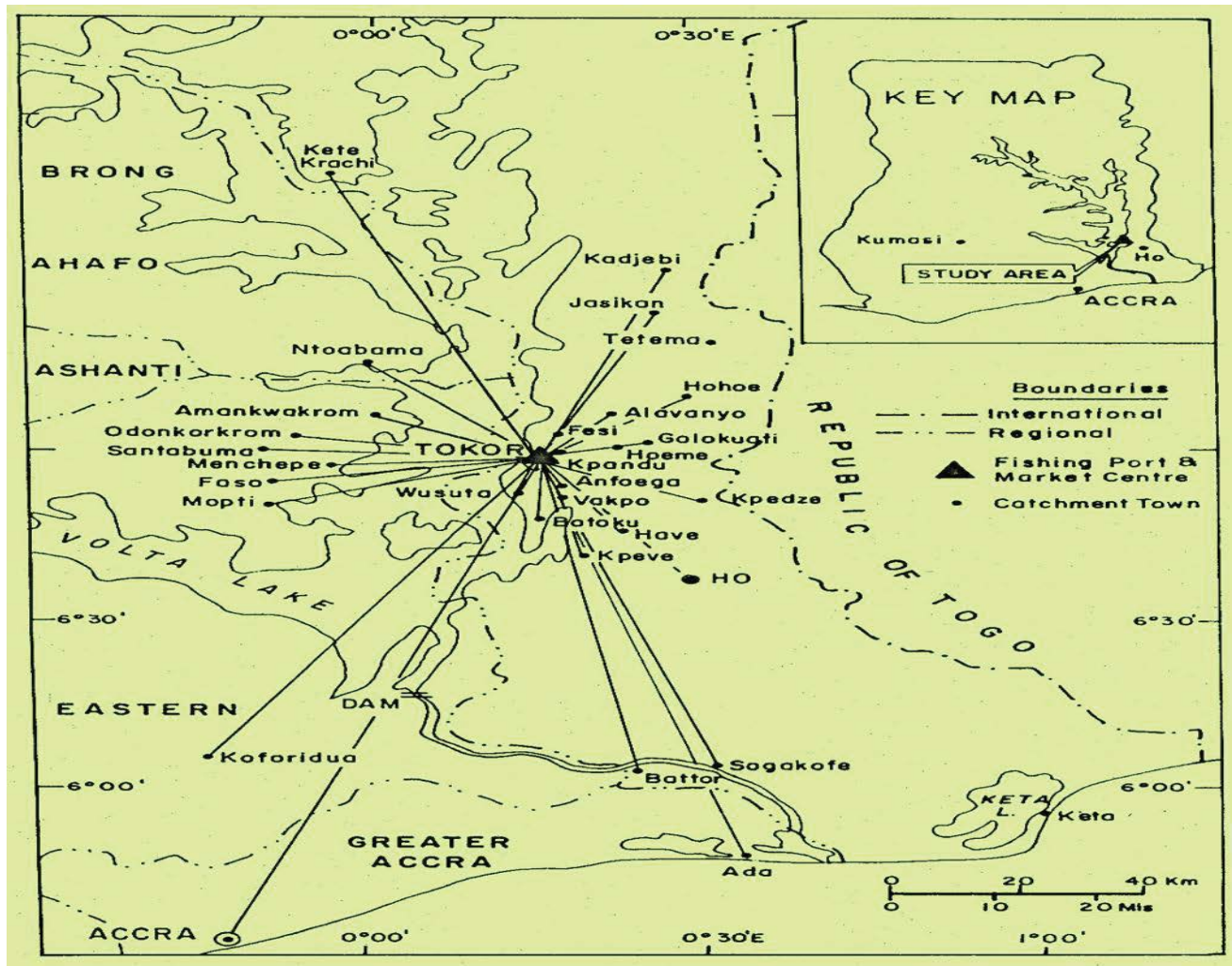

Figure 1: Map of the study area. 
Citation: Gbeddy G, Glover E, Doyi I, Frimpong S, Doamekpor L (2015) Assessment of Organochlorine Pesticides in Water, Sediment, African Cat fish and Nile tilapia, Consumer Exposure and Human Health Implications, Volta Lake, Ghana. J Environ Anal Toxicol 5: 297. doi:10.4172/2161. 0525.1000297

Page 3 of 8

\section{Sample preparation and treatment}

All organic solvents used for this process were of either HPLC or analytical grade.

\section{Water sample extraction and clean up}

Extraction (liquid-liquid) of water samples was executed in accordance with procedures outlined in Deutsche Forschungsgemeinschaft Pesticide Commission's Manual of Pesticide Residue Analysis Volume I and II [14]. Composite water samples obtained by mixing three water samples obtained from a sampling site were filtered through $0.45 \mu \mathrm{m}$ Whatman fiber glass filters to remove debris and suspended material [15].

$\mathrm{pH}$ of the samples was checked to ensure that it was neutral to avert the organochlorine pesticides from undergoing chemical reactions. After filtration, $500 \mathrm{~mL}$ water sample was measured into a $500 \mathrm{~mL}$ capacity separatory funnel followed by the addition of $20 \mu \mathrm{L}$ of $0.02 \mathrm{ppm}$ Internal Standard (isodrin) and $15 \mathrm{~mL}$ saturated $\mathrm{NaCl}$ solution. The water sample was partitioned with $50 \mathrm{~mL}$ dichloromethane (methylene chloride) thrice by shaking the separatory funnel vigorously for 2-3 minutes with intermittent release of pressure. The layers were allowed to separate for 10 minutes. The three extracts of dichloromethane layers were combined into a $250 \mathrm{~mL}$ round bottom flask and then concentrated to about $1-2 \mathrm{~mL}$ using rotary vacuum evaporator. $10 \mathrm{~mL}$ dichloromethane was added for adsorption chromatography. Clean-up was done by column chromatography packed with activated silica gel $5 \mathrm{~g}\left(2 \mathrm{hr}\right.$ at $\left.130^{\circ} \mathrm{C}\right)$ packed between two layers of sodium sulfate $(2.5 \mathrm{~g}$ each) and the column eluted with $20 \mathrm{~mL}$ dichloromethane. Eluate was collected and concentrated to dryness using rotary vacuum evaporator at $40^{\circ} \mathrm{C}$. Final samples were prepared in $1 \mathrm{~mL}$ ethyl acetate for GC-ECD (Electron Capture Detector) analysis.

\section{Fish and sediment samples processing, extraction and clean up}

Fish samples were kept at $-20^{\circ} \mathrm{C}$ until analysis within one week of sampling. The fish samples were taken from the deep freezer and thawed. The total length and body weight of the fishes were measured using a meter rule and weighing balance respectively. The muscle tissue was dissected between the dorsal and ventral portions of the fish and minced into smaller pieces using a warring blender. The operculum was also cut off leading to the subsequent removal of the gills. Three fish samples were pooled to form a composite sample of homogenized muscle tissue or gills. Subsamples were then used in the analysis.

The air dried sediment was crushed, mixed thoroughly and then sieved through $250 \mu \mathrm{m}$ stainless steel mechanical shaker.

Extraction of fish and sieved sediment samples was carried out according to procedures described by Stoichev et al. [3] and Darko et al. [15]. About $10 \mathrm{~g}$ portion of homogenized fish muscle or gill tissues was weighed into a mortar containing $30 \mathrm{~g}$ of anhydrous sodium sulphate ( $35 \mathrm{~g}$ in case of gills) and ground thoroughly using a pestle. The sample was then transferred into an extraction thimble that had been pre-cleaned with $\mathrm{n}$-hexane and acetone and oven dried. $10 \mathrm{~g}$ of sediment sample was transferred into extraction thimble that had been previously washed with n-hexane and acetone and oven dried. $20 \mu \mathrm{L}$ of $0.02 \mathrm{ppm}$ internal standard (isodrin) was added to all the thimble mixtures prior to extraction.

The samples were then Soxhlet extracted with $150 \mathrm{ml}$ of n-hexanedichloromethane 1:3 v/v mixtures for 10 hours. The heated extraction rack accommodates three Soxhlet units. The Soxhlet was monitored occasionally during the extraction to ensure that recycling proceeds satisfactorily. After the extraction period, the heating plate was switch off and allowed to cool. The extraction unit was disassembled first by detaching the condensers from each Soxhlet chamber. By gently tilting the extraction chamber, the solvent was induced to siphon into the sample flask. The extract was evaporated to dryness using a rotary evaporator at $40^{\circ} \mathrm{C}$ extract and then dissolved in $10 \mathrm{ml} \mathrm{n}$-hexane and subjected to clean-up; activated $\mathrm{Cu}$ powder was added in a stepwise manner and in very small amounts to the sediment extract to remove any sulphur that might be present; the $\mathrm{Cu}$ powder will turn black as a result of oxidation if sulphur is present; the addition continued until this reaction seized.

About $3 \mathrm{~g}$ of activated florisil was weighed and poured into a glass column which has been plugged with glass wool and packed very well followed by $1.5 \mathrm{~g}$ layer of anhydrous sodium sulphate. The column was filled with $5 \mathrm{ml}$ portions of hexane and the stopcock was opened to let hexane run out while taping the column to settle the florisil until hexane just reached the top of the sodium sulfate. The sample extract was then transferred onto the florisil column, and eluted with $10 \mathrm{ml}$ portions of hexane using Pasteur pipette. The eluate was collected into a round bottom flask and evaporated to dryness using a rotary evaporator and dissolved in $1 \mathrm{ml}$ of ethyl acetate for GC- ECD analysis. The lipid content of the fish samples was determined gravimetrically.

\section{Instrumental analysis}

A Varian CP-3800 High Resolution Gas Chromatograph (Varian Associates Inc. USA) equipped with an on-column injector and ECD was used for organochlorine pesticide analysis. Sample extract of 1 $\mu \mathrm{l}$ aliquots was injected and the separation was performed on a fused silica gel capillary column (VF- $5 \mathrm{~ms}, 40 \mathrm{~m} \times 0.25 \mathrm{~mm}$ id, $0.25 \mu \mathrm{m}$ film thickness). The carrier gas was ultra-pure nitrogen at a flow rate of $1.0 \mathrm{ml} / \mathrm{min}$. The detector make-up gas was also ultra-pure nitrogen at a flow rate of $29 \mathrm{ml} / \mathrm{min}$. The injector and detector temperatures were $270^{\circ} \mathrm{C}$ and $300^{\circ} \mathrm{C}$ respectively. The column oven temperature was programmed at an increasing rate of $25^{\circ} \mathrm{C} / \mathrm{min}$ from an initial temperature of $70^{\circ} \mathrm{C} ; 2 \mathrm{~min}$ hold to a temperature of $180^{\circ} \mathrm{C} ; 1 \mathrm{~min}$ hold and then, at a rate of $5^{\circ} \mathrm{C} / \mathrm{min}$, to $300^{\circ} \mathrm{C}$. The total run time for a sample was $31.40 \mathrm{~min}$. The pesticide residue was identified and quantified based on comparison of the measured relative retention time, peak height and peak area of samples to those of known standards. These estimated concentrations were not corrected for the varied recoveries obtained in this study. The Limit of Quantification (LOQ) was estimated as 10 times the signal: noise ratio of the blank.

\section{Quality assurance and data handling}

The quality of organochlorine pesticides data was guaranteed through the analysis of solvent blanks, procedure blanks and duplicate samples as well as spiking with an internal standard, Isodrin and analysis of Certified Reference fish Material obtained from the United Nation Environmental Programme (UNEP). A mixed standard of fifteen organochlorine pesticides with concentrations of $0.005,0.01$, 0.02 , and 0.05 were plotted against the peak area to obtain a calibration curve. The area of the curve had $\mathrm{R}^{2}=0.996$. Recalibration curves were run with each batch of samples to check that the correlation coefficient was kept above 0.99 . The method for analysis was optimized and validated by spiking fish, water and sediment samples with $20 \mu \mathrm{L}$ of $0.02 \mathrm{ppm}$ internal standard (isodrin). Spiked samples were taken through same procedure for samples, and the isodrin was measured with good recoveries between $85 \%$ and $105 \%$. The certified reference fish material analyzed consisted of $\mathrm{p}, \mathrm{p}^{1}-\mathrm{DDE}, \mathrm{p}, \mathrm{p}^{1}-\mathrm{DDD}$ and dieldrin; 
Citation: Gbeddy G, Glover E, Doyi I, Frimpong S, Doamekpor L (2015) Assessment of Organochlorine Pesticides in Water, Sediment, African Cat fish and Nile tilapia, Consumer Exposure and Human Health Implications, Volta Lake, Ghana. J Environ Anal Toxicol 5: 297. doi:10.4172/21610525.1000297

Page 4 of 8

their respective recoveries were $75 \%, 112 \%$ and $82 \%$.

Data generated from this study were evaluated statistically using 2010 MS Excel and SPSS 16.0. One-way analysis of variance (ANOVA) and Pearson's Product Moment Correlation (rp) were used to determine whether analytes varied significantly between various samples and were considered statistically significant if $p<0.05$.

\section{Results and Discussion}

\section{General contamination description}

Fifteen organochlorine pesticide (OCP) residues namely $\beta-\mathrm{HCH}$, $\gamma$-HCH, $\delta$-HCH, p,p'-DDT, p,p'-DDD, p,p'-DDE, heptachlor, aldrin, dieldrin, endrin, $\gamma$-chlordane, $\alpha$-endosulfan, $\beta$-endosulfan, endosulfan sulphate and methoxychlor were considered in this study. Thirteen of them (excluding $\gamma-\mathrm{HCH}$ and endrin) were detected and quantified in catfish, tilapia and sediment samples (Tables 1 and 2) with concentrations ranging from below limit of quantification (LOQ) to $37.75 \mathrm{ng} / \mathrm{g}$ wet weight (ww) or dry weight (dw) whilst twelve OCPs (except $\gamma$-HCH, p,p'-DDT and endrin) were detected in water samples (Table 2) with concentration ranging from below LOQ to $0.669 \mu \mathrm{g} / \mathrm{L}$.

From the statistical analysis conducted the mean concentrations of all organochlorine pesticide residues in Nile tilapia muscle and African catfish muscle did not differ significantly $(\mathrm{p}<0.05)$. The mean concentrations of most OCP residues in Nile tilapia muscle and gill did not differ significantly except $\delta-\mathrm{HCH}$, heptachlor and aldrin $(\mathrm{p}<0.05)$. Nile tilapia muscle and catfish muscle tissues OCP levels showed a very strong linear relationship with a correlation coefficient of 0.957 . There is therefore, a high probability of exposure by these tissues to similar source of organochlorine pesticide residues in the aquatic ecosystem.

In accordance with their lipophilicity, the total OCP load (i.e. the sum of the means of all detected OCPs in a particular sample) of sediment samples was relatively low compared to fish samples analyzed. Heptachlor was the highest level of OCP measured in this study with a concentration of $37.75 \mathrm{ng} / \mathrm{g}$ in Nile tilapia gill tissues followed by $\delta-\mathrm{HCH}$ in tilapia muscle and catfish muscle tissues respectively as shown in Figure 2.

In exception of p,p'-DDT, p,p'-DDE, heptachlor and methoxychlor, the levels of OCPs in Nile tilapia gill tissues were generally lower than those of its corresponding muscle tissues as indicated in Figure 3. $\mathrm{x}$ was recorded in tilapia muscle tissue, followed by $63.44 \mathrm{ng} / \mathrm{g}$ ww estimated for tilapia gill. This observation however contradicts the lipophilic nature of OCPs since the fat content of tilapia gill (14.49\%) was five times that of its muscle $(2.80 \%)$. The effects of pesticide residues on fish, as on other vertebrates, will depend in part on the condition of the fish, which is primarily determined by the lipid content of the tissues. In times of physiological stress, such as starvation or spawning, these lipid reserves are metabolized, and the pesticide content of the remaining lipids will be increased, perhaps to a level at which the pesticide circulating in the vascular system may become toxic for some target organs or nerve centre [16]. Tilapia gill was analyzed in this study since it constitutes a major delicacy in the head for most tilapia consumers in Ghana. This is coupled with the fact that much higher levels of OCPs were measured in gills by Yang et al. [17] in fish from high mountain lakes and Lhasa River in the Tibetan Plateau of China. This could be explained by its larger surface areas per gram of tissue since gills continuously transfer organic pollutants from both water and suspended particles onto its surface. This was however, not the exact picture in this current study thus the need for further investigation to collaborate and also illuminate this observed discordance.

\section{OCP residues analysis in water}

The frequency of occurrence of organochlorine pesticides in water samples was very small with $29 \%$ as the highest recorded by $\beta-\mathrm{HCH}$, p,p'-DDD, dieldrin, endosulfan sulphate and methoxychlor. This observation was expected since organochlorine pesticides by their nature are hydrophobic. $\delta$ - $\mathrm{HCH}$ had the highest mean concentration of $0.669 \mu \mathrm{g} / \mathrm{L}$ with occurrence frequency of $14 \%$. This was followed by $\beta-\mathrm{HCH}$, heptachlor and endosulfan sulphate with concentrations of $0.194,0.075$ and $0.039 \mu \mathrm{g} / \mathrm{L}$ respectively (Figure 4).

The existence of these organochlorine pesticide residues in the water could be attributed to varied sources, mainly from past agricultural and household usage. Natural processes such as leaching and run-off are likely to enhance their transfer to the main course of the lake, especially during the rainy season coupled with irrigation activities. Bad fishing practices such as the use of pesticides to boost cache are other plausible ways where these chemicals can be poured into the water [11]. Empty pesticide containers were also observed floating on the lake during sampling as cork support for fishing nets. This ill-practice must be discouraged among the fisher folks around this all important lake.

\section{OCP residues analysis in sediment samples}

The prevalent organochlorine pesticide residues in sediment samples were endosulfan sulphate, $\beta-\mathrm{HCH}, \delta-\mathrm{HCH}$, heptachlor, methoxychlor, $\alpha$-endosulfan and dieldrin with mean concentrations of $1.39,1.16,1.14,1.11,0.90,0.89$ and $0.82 \mathrm{ng} / \mathrm{g} \mathrm{dw}$ respectively (Table 2 and Figure 5). $\beta-\mathrm{HCH}, \mathrm{p}, \mathrm{p}-\mathrm{DDD}, \delta-\mathrm{HCH}$, endosulfan sulphate and heptachlor had the highest occurrence frequencies ranging from 83 to $100 \%$ (Table 2).

The mean concentration and occurrence frequencies of organochlorine pesticide residues in sediment samples were higher than those found for water samples, and this could be due to their accumulation in sediment over time. Their high stability in soil (halflife between 50 days and 15 years) and transportation of contaminated suspended particulate matter where sediment serve as a major sink could all be contributory factors for this observation. The longer resident time of pesticide residues in sediment may increase their risk to the lakes aquatic life, especially benthic fauna [11].

\section{Comparison of individual OCP residues among various samples}

DDT: DDT was not detected in both water and sediment samples (Table 2). Ntow [11] also reported no DDT in water samples from the Volta Lake but was measured in sediment samples with mean concentration of $9.00 \mathrm{ng} / \mathrm{g} \mathrm{dw}$. DDT was however, detected in all fish samples analyzed and can be attributed to its lipophilicity and bioaccumulation properties. The highest mean concentration of $0.67 \mathrm{ng} / \mathrm{g}$ ww was measured in tilapia gill tissue followed by tilapia muscle. This trend is feasible since gill seems to accumulate more organochlorine pesticides due to absorption by its larger surface per tissue [17].

Adu-Kumi et al. [18] however reported very high values of DDT (520.00; o, $\mathrm{p}^{1}-\mathrm{DDT}$ and $1600.00 \mathrm{ng} / \mathrm{g}$ lipid weight; $\mathrm{p}, \mathrm{p}^{1}-\mathrm{DDT}$ ) in catfish obtained from the Madina market a suburb of Accra. These samples were believed to have originated from the Volta Lake. These extremely high levels therefore, lend credence to the speculation that some market women may apply pesticides on fish and fish products to prevent flies from invading them.

$\mathrm{p}, \mathrm{p}^{1}-\mathrm{DDD}$ and $\mathrm{p}, \mathrm{p}^{1}-\mathrm{DDE}$, two metabolites of $\mathrm{p}, \mathrm{p}^{1}-\mathrm{DDT}$ were, 
Citation: Gbeddy G, Glover E, Doyi I, Frimpong S, Doamekpor L (2015) Assessment of Organochlorine Pesticides in Water, Sediment, African Cat fish and Nile tilapia, Consumer Exposure and Human Health Implications, Volta Lake, Ghana. J Environ Anal Toxicol 5: 297. doi:10.4172/21610525.1000297

Page 5 of 8

\begin{tabular}{|c|c|c|c|}
\hline \multirow{3}{*}{ OCP residue } & \multicolumn{3}{|c|}{ Mean concentrations (ng/g) } \\
\hline & \multicolumn{2}{|c|}{ Tilapia } & \multirow{2}{*}{$\begin{array}{c}\text { Catfish } \\
\text { Muscle tissue }\end{array}$} \\
\hline & Muscle tissue & Gill tissues & \\
\hline$\beta-\mathrm{HCH}$ & $8.22 \pm 8.15$ & $7.84 \pm 3.06$ & $2.78 \pm 2.95$ \\
\hline$\delta-\mathrm{HCH}$ & $33.40 \pm 24.95$ & $5.08 \pm 5.54$ & $17.35 \pm 13.78$ \\
\hline $\mathrm{p}, \mathrm{p}^{\prime}-\mathrm{DDT}$ & $0.53 \pm 0.35$ & $0.67 \pm 0.24$ & $0.25 \pm 0.07$ \\
\hline$p, p^{\prime}-D D D$ & $10.06 \pm 9.21$ & $1.79 \pm 0.71$ & $1.71 \pm 1.42$ \\
\hline$p, p^{\prime}-D D E$ & $0.15 \pm 0.06$ & $1.35 \pm 0.36$ & $0.3 \pm 0.28$ \\
\hline Heptachlor & $4.02 \pm 1.30$ & $37.75 \pm 32.31$ & $4.73 \pm 5.02$ \\
\hline Aldrin & $1.14 \pm 0.83$ & $<\mathrm{LOQ}$ & $0.89 \pm 0.53$ \\
\hline Dieldrin & $1.29 \pm 1.21$ & $0.59 \pm 0.14$ & $0.10 \pm 0.06$ \\
\hline Y-Chlordane & $1.02 \pm 1.01$ & $0.84 \pm 0.85$ & $0.49 \pm 0.30$ \\
\hline a-Endosulfan & $1.34 \pm 0.49$ & $0.56 \pm 0.21$ & $0.59 \pm 0.40$ \\
\hline$\beta$-Endosulfan & $0.64 \pm 0.76$ & $0.62 \pm 0.31$ & $1.18 \pm 0.92$ \\
\hline Endosulfan sulphate & $1.13 \pm 1.24$ & $0.95 \pm 1.27$ & $0.67 \pm 0.36$ \\
\hline \multirow[t]{2}{*}{ Methoxychlor } & $3.76 \pm 3.30$ & $5.40 \pm 1.74$ & $2.19 \pm 1.88$ \\
\hline & 66.70 & 63.44 & 33.23 \\
\hline
\end{tabular}

Table 1: Summary of the results of analysis for OCP residues in Tilapia zilli and African Catfish.

\begin{tabular}{|c|c|c|c|c|c|c|}
\hline \multirow{2}{*}{ OCP residue } & \multicolumn{3}{|c|}{ Water, $\mu \mathrm{g} / \mathrm{L}$} & \multicolumn{3}{|c|}{ Sediment, ng/g, dw } \\
\hline & Range & Mean \pm SD & $\%$ Occur & Range & Mean \pm SD & $\%$ Occur. \\
\hline$\beta-\mathrm{HCH}$ & $<L O Q-0.384$ & $0.194 \pm 0.270$ & 29 & $0.20-2.68$ & $1.16 \pm 0.89$ & 100 \\
\hline$\delta-\mathrm{HCH}$ & $<L O Q-0.669$ & $0.669 \pm 0.457$ & 14 & $<L O Q-2.48$ & $1.14 \pm 0.79$ & 86 \\
\hline $\mathrm{p}, \mathrm{p}^{\prime}-\mathrm{DDT}$ & - & - & - & - & - & - \\
\hline$p, p^{\prime}-D D D$ & $<L O Q-0.031$ & $0.022 \pm 0.013$ & 29 & $0.20-1.39$ & $0.60 \pm 0.43$ & 100 \\
\hline$p, p^{\prime}-D D E$ & $<L O Q-0.011$ & $0.011 \pm 0.006$ & 14 & $<L O Q-1.39$ & $0.63 \pm 0.66$ & 43 \\
\hline Heptachlor & $<L O Q-0.075$ & $0.075 \pm 0.046$ & 14 & $<\mathrm{LOQ}-4.97$ & $1.11 \pm 1.90$ & 83 \\
\hline Aldrin & $<L O Q-0.025$ & $0.025 \pm 0.018$ & 14 & $<L O Q-0.30$ & $0.30 \pm 0.22$ & 14 \\
\hline Dieldrin & $<L O Q-0.031$ & $0.017 \pm 0.019$ & 29 & $<L O Q-1.68$ & $0.82 \pm 0.61$ & 57 \\
\hline Y-Chlordane & $<L O Q-0.009$ & $0.009 \pm 0.004$ & 14 & $<L O Q-1.09$ & $0.43 \pm 0.57$ & 43 \\
\hline a-Endosulfan & - & - & - & $<L O Q-0.89$ & $0.89 \pm 0.65$ & 14 \\
\hline$\beta$-Endosulfan & $<L O Q-0.002$ & $0.002 \pm 0.001$ & 14 & $<\mathrm{LOQ}-1.19$ & $0.45 \pm 0.50$ & 57 \\
\hline Endosulfan sulphate & $<L O Q-0.076$ & $0.039 \pm 0.052$ & 29 & $0.00-2.68$ & $1.39 \pm 0.92$ & 86 \\
\hline \multirow[t]{2}{*}{ Methoxychlor } & $<L O Q-0.013$ & $0.007 \pm 0.008$ & 29 & $<\mathrm{LOQ}-2.49$ & $0.90 \pm 1.09$ & 57 \\
\hline & & & & & 'Load=9.82 & \\
\hline
\end{tabular}

Table 2: Synopsis of the results of analysis for OCP residues in water and sediment samples.

however, measured in both water and sediment samples. p, $\mathrm{p}^{1}$-DDD was detected in $100 \%$ of sediment samples at $0.60 \mathrm{ng} / \mathrm{g} \mathrm{dw}$ and $\mathrm{p}, \mathrm{p}^{1}$ DDE in $43 \%$ of sediment samples at $0.63 \mathrm{ng} / \mathrm{g} \mathrm{dw}$ (Table 2). This could be due to the decomposition of DDT used in the past.

p, $\mathrm{p}^{1}$-DDD was measured in $100 \%$ of all fatty tissues analyzed with the highest mean concentration of $10.06 \mathrm{ng} / \mathrm{g}$ ww in tilapia muscle. Tilapia gill however had the highest $\mathrm{p}, \mathrm{p}^{1}$-DDE mean concentration of $1.35 \mathrm{ng} / \mathrm{g}$ but with the least occurrence frequency of $17 \%$.

DDT concentrations in fish from around the world have been reported [19-22]. The average DDT concentration of $0.48 \mathrm{ng} / \mathrm{g}$ ww obtained in this current study for fish samples was lower than that in Liaoning province $(18.54 \mathrm{ng} / \mathrm{g})$, Vietnam $(26 \mathrm{ng} / \mathrm{g})$, Indonesia $(28$ $\mathrm{ng} / \mathrm{g})$, Australia (22 ng/g), India (15 ng/g), Thailand (6.2 ng/g), Korea $(8.96 \mathrm{ng} / \mathrm{g})$, Sweden $(7.02 \mathrm{ng} / \mathrm{g})$, Solomon Islands $(4.8 \mathrm{ng} / \mathrm{g})$ and Salton Sea, USA (17.6 ng/g) but slightly higher than that in Papua New Guinea $(0.43 \mathrm{ng} / \mathrm{g})$.
DDT can be biodegraded into DDE under aerobic conditions and DDD under anaerobic conditions and a value of $(D D T \div(D D D+D D E))>1$ can be used as an indicator of possible new sources of DDT. From this study, all the $(D D T \div(D D D+D D E))$ values obtained were $<1$ in $100 \%$ of samples. This therefore, suggests that DDT concentrations in fish from the Volta Lake were mainly due to historical use, even though the existence of point and non-point sources cannot be totally ruled-out. It can also be a confirmation of the high rate of degradation of DDT under hot, dry climatic conditions as reported by Jiries et al. [4] which is typical of tropical environment. Thus when the use of DDT ceases in this part of the world, the levels of this chemical decreases more rapidly.

Hexachlorocyclohexane (HCH): $\gamma-\mathrm{HCH}$ (lindane) was not detected in any of the samples analyzed; however, $\beta-\mathrm{HCH}$ and $\delta-\mathrm{HCH}$ were measured in all samples with varying concentrations and occurrence frequencies. $\beta-\mathrm{HCH}$ was detected in $29 \%$ of water samples analyzed, and $100 \%$ of both sediment and fish samples. $\delta$ - $\mathrm{HCH}$ recorded the highest concentration of $0.669 \mu \mathrm{g} / \mathrm{L}$ among all 
Citation: Gbeddy G, Glover E, Doyi I, Frimpong S, Doamekpor L (2015) Assessment of Organochlorine Pesticides in Water, Sediment, African Cat fish and Nile tilapia, Consumer Exposure and Human Health Implications, Volta Lake, Ghana. J Environ Anal Toxicol 5: 297. doi:10.4172/21610525.1000297

Page 6 of 8

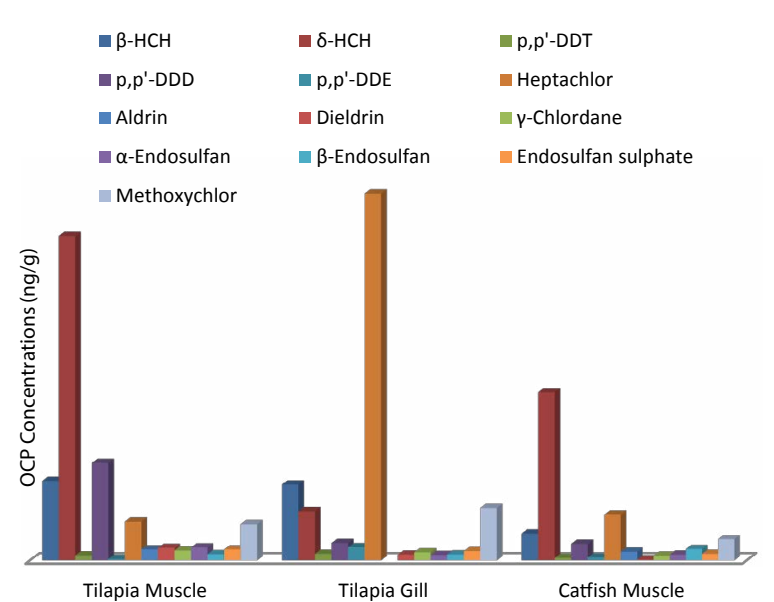

Figure 2: Diagram showing the OCP levels across various fish tissues.

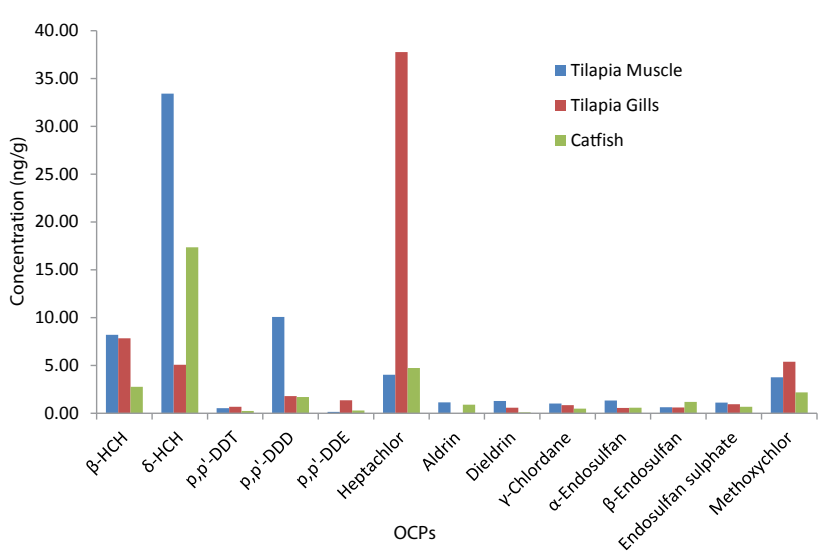

Figure 3: Diagram indicating the comparative levels of OCPs in fish tissues.

the organochlorine pesticide residues analyzed for in water but with an occurrence frequency of $14 \%$ (Tables 1 and 2).

The average of the mean concentrations of $\beta-\mathrm{HCH}$ and $\delta-\mathrm{HCH}$ measured in sediment samples was $1.15 \mathrm{ng} / \mathrm{g} \mathrm{dw}$; this value is about half the average Lindane concentration reported by Ntow [11] in sediment samples from the Volta Lake.

The concentration for $\beta-\mathrm{HCH}$ and $\delta-\mathrm{HCH}$ ranged from 0.39 to $60.70 \mathrm{ng} / \mathrm{g} \mathrm{ww}$ in all fish samples tested; this is incomparable to 0.70 to $1.36 \mathrm{ng} / \mathrm{g}$ ww reported by Darko et al. [15] for lindane in tilapia fish from Lake Bosomtwi, Ghana.

The average of the mean concentrations of both $\beta-\mathrm{HCH}$ and $\delta$ - $\mathrm{HCH}$ in fish samples, $12.45 \mathrm{ng} / \mathrm{g}$ ww in this study is more than 0.126 $\mathrm{ng} / \mathrm{g}$ lipid weight measured for Lindane in tilapia obtained from Lake Bosomtwi by Darko et al. [15]. It is also higher than $\mathrm{HCH}$ mean values in fish in Sweden $(0.96 \mathrm{ng} / \mathrm{g})$ [22], Thailand $(0.82 \mathrm{ng} / \mathrm{g})$, Australia $(0.34 \mathrm{ng} / \mathrm{g})$, Indonesia (0.73 ng/g), Papua New Guinea $(0.57 \mathrm{ng} / \mathrm{g})$, the Solomon Islands (0.53 ng/g) [19], Korea (0.94 ng/g) [21] and Vietnam $(1.8 \mathrm{ng} / \mathrm{g})$ [19] but lower than that in India $(28 \mathrm{ng} / \mathrm{g})$ [19].

Endosulfan: Technical endosulfan consists of $\alpha$ - and $\beta$ - isomers. It is one of the few cyclodiene pesticides that are still used extensively throughout the world to control a number of insect pests on crops.
In the environment, the cyclic sulphite group of endosulfan can be oxidized to the corresponding sulphate (endosulfan sulphate) [23-25], which is persistent than its parents [26].

All isomers and metabolite of endosulfan were detected in all samples analyzed except $\alpha$-endosulfan in water. endosulfan concentration ranged from $<\mathrm{LOQ}$ to $1.43 \mathrm{ng} / \mathrm{g}$ for sediment and fish samples. This is narrow compared to 0.33 to $14.40 \mathrm{ng} / \mathrm{g}$ reported by Darko et al. [15] in similar samples from Bosomtwi Lake, Ghana. The average of the mean concentrations of endosulfan in water, $0.021 \mu \mathrm{g} / \mathrm{L}$ compares positively with $0.028 \mu \mathrm{g} / \mathrm{L}$ reported by Ntow [11] in Volta Lake. The average concentration of $0.91 \mathrm{ng} / \mathrm{g} \mathrm{dw}$ for endosulfan in sediment was lower than $9.68 \mathrm{ng} / \mathrm{g}$ obtained by Darko et al. [15] but higher than $0.25 \mathrm{ng} / \mathrm{g}$ reported by Ntow [11] in Volta Lake, Ghana.

\section{Consumer exposure to OCPs and health implications}

Water: The acute risk ratio (ARR) was calculated by comparing the pesticide concentrations in the water in this study with toxicity values. The highest pesticide concentration determined was used for each detected OCP residue [27], in comparison with the LC50 for each corresponding residue for fish.

The USEPA has set specific maximum levels of certain pesticides that are allowed in drinking water known as maximum contaminant level (MCL). These values are based on scientific data from long term animal studies. By drinking water that contains pesticides $\leq \mathrm{MCL}$, humans are not expected to be at a higher risk for health problems.

In comparison with the World Health Organization's (WHO) guideline values for OCP residues only heptachlor exceeded its limit. However, its occurrence frequency was $14 \%$ in the water samples examined. Therefore, there is a possibility of dilution as the water mixed up thereby reducing this level recorded in this study. On the whole, water from the lake can be said to be relatively safe for both domestic and ranching purposes.

From Table 3 above, none of the detected organochlorine pesticide has ARR $>1$. These pesticide residues concentrations can therefore, pose little or no risk to the organisms in the lake's ecosystem particularly allimportant fish population.

However, the simultaneous exposure to multiple pesticide residues may lead to an additive, potentiating, antagonizing or synergistic effect. Thus, one cannot say for certainty that these organochlorine pesticide residues detected in the water are of no risk even though ARR values are less than one. Further research might be needed to assess the presence or absence of any such effects on aquatic organisms exposed to such multiple pollutants.

The MCL for most of the OCP residues are not available, thereby making assessment of their potential risk to man very difficult. Heptachlor was, however, found to be below its corresponding MCL hence will not pose any significant risk to man in the water.

Fish: This analysis estimated human exposure to various detected OCP residues through fish consumption by combining data on contaminant concentration in fish, which is commonly used to assess human risk [28].

According to the Food and Agriculture Organization (FAO) of the U.N, Ghana's per capita consumption of fish is estimated at $25 \mathrm{~kg} /$ year [29] which is equivalent to $68.5 \mathrm{~g} /$ day. Even though this figure might not be the exact figure for fish obtained from the Volta Lake to the Ghanaian fish consumer, it is assumed to be the case in this current 
Citation: Gbeddy G, Glover E, Doyi I, Frimpong S, Doamekpor L (2015) Assessment of Organochlorine Pesticides in Water, Sediment, African Cat fish and Nile tilapia, Consumer Exposure and Human Health Implications, Volta Lake, Ghana. J Environ Anal Toxicol 5: 297. doi:10.4172/2161. 0525.1000297

Page 7 of 8

study.

\section{Estimation of Daily intake of organochlorine pesticide (OCP) residues via fish consumption.}

The dietary intake of OCP residues was estimated by multiplying the pesticide concentration measured in each fish tissue by the per capita consumption and the result of analysis are shown (Table 4).

Dietary Intake $=$ OCP residue concentration $\mathrm{x}$ per capita fish consumption

The greatest potential exposure of consumers to organochlorine pesticide residues was to $\mathrm{HCH}$ in tilapia muscle $(2.9 \mu \mathrm{g} /$ person/day $)$ followed by heptachlor in tilapia gill $(2.6 \mu \mathrm{g} /$ person/day) (Table 4$)$.

Fish is recognized as the most important source of animal protein in all regions of Ghana. Estimates suggest that over $60 \%$ of animal protein in the Ghanaian diet comes from fish [29]. From this study, it is noted that the exposure of humans to OCP residues could be due to consumption of tilapia fish (Table 5). It is vital to note however, that none of the estimated daily dietary intakes exceeded the corresponding ADI recommended by Health Canada [30] and IARC [31]. OCPs can however, bioaccumulate and biomagnify, it is therefore necessary to adopt all the necessary measures of minimizing exposure to forestall any deleterious chronic effect associated with these chemicals; prevention is always better than cure.

There are however, certain strategies that can be adopted to minimize the rate of exposure to OCP residues through tilapia consumption. The number of times one consumes tilapia especially from the Volta Lake in a day can be reduced. Moreover, prior to preparation and consumption certain parts such as the gills can be removed particularly by those who consume whole tilapia [32].

Tilapia consumers can also endeavor to include other fish species whose OCP bioaccumulation and bio-magnification factors are very minimal in their delicacy so as to reduce their over dependence on tilapia for their fish protein. This will go a long way in safeguarding their long term health.

\section{Acknowledgement}

The authors of this paper will like to express their profound gratitude to the following individuals for their diverse contributions to the successful conduct of this research: Prof. Derick Carboo, Chemistry Department, University of Ghana Prof. Philip Yeboah of Christ Apostolic University Ghana; Paul Osei-Fosu of Ghana Standard Authority and Harriet Kuranchie of Ghana Atomic Energy Commission.

\begin{tabular}{|c|c|c|c|c|c|c|}
\hline OCP Residue & $\begin{array}{l}\text { Maximum } \\
\text { conc. }(\mu \mathrm{g} / \mathrm{L})\end{array}$ & $\begin{array}{c}\mathrm{LC}_{50} \\
\operatorname{fish}(\mu \mathrm{g} / \mathrm{L})\end{array}$ & $A R R=\frac{\text { Max.conc } .}{L C 50}$ & $\begin{array}{c}\text { Mean } \\
\text { conc. }(\mu \mathrm{g} / \mathrm{L})\end{array}$ & $\begin{array}{c}M C L \\
(\mu g / L)\end{array}$ & $\begin{array}{l}\text { WHO Guide- } \\
\text { line Value }(\mu \mathrm{g} / \mathrm{L})\end{array}$ \\
\hline$\beta-\mathrm{HCH}$ & 0.384 & 1.70 & 0.2 & 0.194 & NA & 2 \\
\hline$\delta-\mathrm{HCH}$ & 0.669 & 1.70 & 0.4 & 0.669 & NA & 2 \\
\hline$p, p^{\prime}-D D D$ & 0.031 & 0.18 & 0.2 & 0.022 & NA & 2 \\
\hline $\mathrm{p}, \mathrm{p}^{\prime}-\mathrm{DDE}$ & 0.011 & 0.18 & 0.1 & 0.011 & NA & 2 \\
\hline Heptachlor & 0.075 & 5.30 & 0.0 & 0.075 & 0.4 & 0.03 \\
\hline $\mathrm{y}$-Chlordane & 0.009 & 70.00 & 0.0 & 0.009 & NA & NA \\
\hline$\beta$-Endosulfan & 0.002 & 1.20 & 0.0 & 0.002 & NA & NA \\
\hline $\begin{array}{l}\text { Endosulfan } \\
\text { sulphate }\end{array}$ & 0.076 & 1.20 & 0.0 & 0.039 & NA & NA \\
\hline
\end{tabular}

$\mathrm{NA}=$ Not available

Table 3: Detected organochlorine pesticide (OCP) residues in water and associated toxicity data ( ${ }^{\mathrm{b} E X T O X N E T ~ 1996) .}$

\begin{tabular}{|c|c|c|c|c|c|c|c|}
\hline \multirow{2}{*}{ Fish Tissue } & \multicolumn{7}{|c|}{ Estimated dietary intake ( $\mu \mathrm{g} /$ person/day) } \\
\hline & $\sum \mathrm{HCH}$ & $\sum \mathrm{DDT}$ & Heptachlor & Dieldrin & ү-Chlordane & $\sum$ Endosulfan & Methoxychlor \\
\hline Tilapia muscle & 2.9 & 0.7 & 0.3 & 0.1 & 0.1 & 0.2 & 0.3 \\
\hline Tilapia gill & 0.8 & 0.2 & 2.6 & 0.0 & 0.1 & 0.1 & 0.4 \\
\hline $\begin{array}{c}\text { Mean Dietary } \\
\text { Intake }\end{array}$ & 1.9 & 0.5 & 1.5 & 0.1 & 0.1 & 0.2 & 0.4 \\
\hline
\end{tabular}

Table 4: The estimated dietary intake ( $\mu \mathrm{g} / \mathrm{person} /$ day) of OCP residues via the consumption of fish obtained from the Volta Lake.

\begin{tabular}{|c|c|c|c|}
\hline Pesticide residue & $\begin{array}{l}\text { Estimated dietary intake (EDI) } \\
(\mu \mathrm{g} / \text { person/day })\end{array}$ & ADI ( $\mu \mathrm{g} /$ person/day) & $\left(\frac{E D I}{A D I}\right) \times 100$ \\
\hline$\sum \mathrm{HCH}$ & 1.9 & $18^{a}$ & $10.6 \%$ \\
\hline$\sum \mathrm{DDT}$ & 0.5 & $300^{b}$ & $0.2 \%$ \\
\hline$\sum$ Endosulfan & 0.2 & $450^{b}$ & $0.04 \%$ \\
\hline Dieldrin & 0.1 & $6^{a}$ & $1.7 \%$ \\
\hline
\end{tabular}

aHealth Canada (1996), 'International Agency for Research on Cancer (IARC), (1989)

Table 5: Comparison of estimated dietary intake (EDI) with the acceptable dietary intake (ADI) stipulated by various statutory agencies 
Citation: Gbeddy G, Glover E, Doyi I, Frimpong S, Doamekpor L (2015) Assessment of Organochlorine Pesticides in Water, Sediment, African Cat fish and Nile tilapia, Consumer Exposure and Human Health Implications, Volta Lake, Ghana. J Environ Anal Toxicol 5: 297. doi:10.4172/21610525.1000297

Page 8 of 8

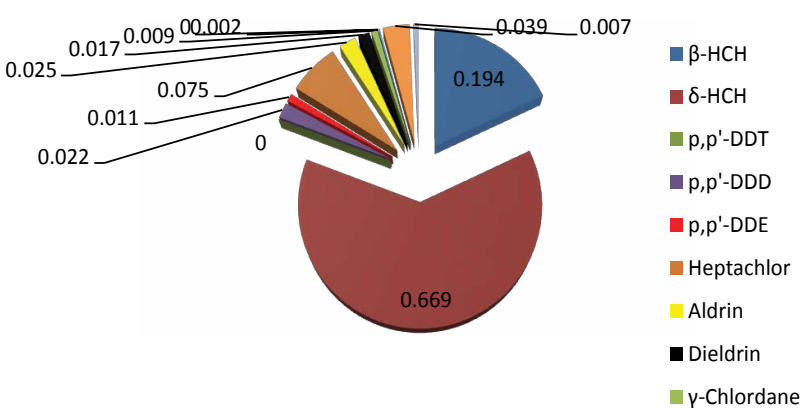

Figure 4: Diagram showing the comparison of the mean OCP concentrations $(\mu \mathrm{g} / \mathrm{L})$ in water samples.

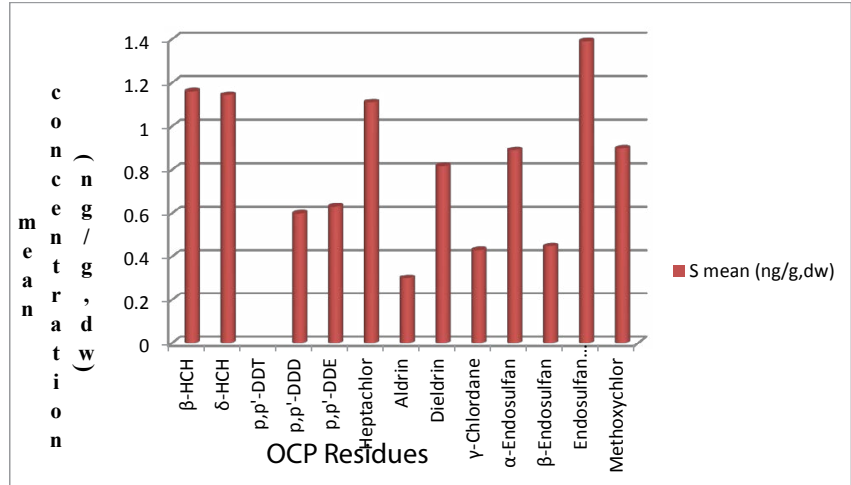

Figure 5: Comparison of estimated dietary intake (EDI) with the acceptable dietary intake $(\mathrm{ADI})$ stipulated by various statutory agencies.

\section{References}

1. BBC News (2015) Nigeria mystery deaths: Pesticides suspected, says WHO

2. Carson R (1962) Silent Spring. (40thedn), Houghton Mifflin Publishing Company, Wilmington, pp 169.

3. Stoichev T, Rizov N, Kolarska A, Ribarova F, Atanassova M (2005) Comparison of Extraction Procedures for Determination of Organochlorine Pesticides in Fish. 40: 251-254.

4. Jiries AG Nasir FM, Beese F (2002) Pesticide and heavy metals residue in wastewater, soil and plants in wastewater disposal site near Al-Lajoun Valley, Karak/Jordan. Water, Air Soil Pollut 133: 97-107.

5. Muir D, Sverko E (2006) Analytical methods for PCBs and organochlorine pesticides in environmental monitoring and surveillance: a critical appraisal. Anal Bioanal Chem 386: 769-789.

6. Baird C (2005) Environmental Chemistry. (3rdedn) W.H. Freeman and Company, New York, USA, pp 307-333.

7. Rajendran RB, Imagawa T, Tao H, Ramesh R (2005) Distribution of PCBs, $\mathrm{HCHs}$ and DDTs, and their ecotoxicological implications in Bay of Bengal, India. Environ Int 31: 503-512.

8. Martínez MP, Angulo R, Pozo R, Jodral M (1997) Organochlorine pesticides in pasteurized milk and associated health risks. Food Chem Toxicol 35: 621-624.

9. Trotter WJ, Dickerson R (1993) Pesticide residues in composited milk collected through the U.S. Pasteurized Milk Network. J AOAC Int 76: 1220-1225.

10. Ntow WJ1 (2001) Organochlorine pesticides in water, sediment, crops, and human fluids in a farming community in Ghana. Arch Environ Contam Toxicol 40: $557-563$

11. Ntow JW (2005) Pesticide residues in Volta Lake, Ghana. Lake and Reservoirs: Research and Management 10: 243-248.

12. Racke KD (1997) Pesticide fate in tropical soils. Pure Appl Chem 69: 1349 1371.
13. Darko G, Acquaah SO (2007) Levels of Organochlorine Pesticides Residues in Meat. Int J Environ Sci Tech 4: 521-524.

14. Thier H, Kirchhoff J (1992) Pesticide Commission's Manual of Pesticide Residue Analysis Volume I and II. Deutsche Forschungsgemeinschaft, DFG. Wiley VCH.

15. Darko G, Akoto O, Oppong C (2008) Persistent organochlorine pesticide residues in fish, sediments and water from Lake Bosomtwi, Ghana. Chemosphere 72: 21-24.

16. Holden AV (1966) Organochlorine Insecticide Residues in Salmonid Fish Journal of Applied Ecology, Volume 3, supplement. Pesticides in the Environment and their Effects on Wildlife, 45-53.

17. Yang R, Yao T, Xu B, Jiang G, Xin X (2007) Accumulation features of organochlorine pesticides and heavy metals in fish from high mountain lakes and Lhasa River in the Tibetan Plateau. Environ Int 33: 151-156.

18. Adu-Kumi S, Kawano M, Shiki Y, Yeboah PO, Carboo D, et al. (2010) Organochlorine pesticides (OCPs), dioxin-like polychlorinated biphenyls (dlPCBs), polychlorinated dibenzo-p-dioxins and polychlorinated dibenzo furans (PCDD/Fs) in edible fish from Lake Volta, Lake Bosumtwi and Weija Lake in Ghana. Chemosphere 81: 675-684.

19. Kannan K, Tanabe S, Tatsukawa R (1995) Geographical distribution and accumulation features of organochlorine residues in fish in tropical Asia and oceania. Environ Sci Technol 29: 2673-2683.

20. Sapozhnikova Y, Bawardi O, Schlenk D (2004) Pesticides and PCBs in sediments and fish from the Salton Sea, California, USA. Chemosphere 55: 797-809.

21. Yim UH, Hong SH, Shim WJ, Oh JR (2005) Levels of persistent organochlorine contaminants in fish from Korea and their potential health risk. Arch Environ Contam Toxicol 48: 358-366.

22. Darnerud PO, Atuma S, Aune M, Bjerselius R, Glynn A, et al. (2006) Dietary intake estimations of organohalogen contaminants (dioxins, PCB, PBDE and chlorinated pesticides, e.g. DDT) based on Swedish market basket data. Food Chem Toxicol 44: 1597-1606.

23. Chandler GT, Scott GI (1991) Effects of sediment-bound endosulfan on survival, reproduction and larval settlement of meiobenthic polychaetes and copepods. Environ Toxicol Chem 10: 375-383.

24. Guerin TF, Kennedy IR (1992) Distribution and dissipation of endosulfan and related cyclodienes in sterile aqueous systems: implications for studies on biodegradation. J Agric Food Chem 40: 2315-2323.

25. Kathpal TS, Singh A, Dhankhar JS, Singh G (1997) Fate of endosulfan in cotton soil under sub-tropical conditions of northern India. Pestic Sci 50: 21-27.

26. Guerin TF (2001) A biological loss of endosulfan and related chlorinated organic compounds from aqueous systems in the presence and absence of oxygen. Environ Pollut 115: 219-230.

27. Castillo LE, Ruepert C, Solis E (2000) Pesticide residues in the aquatic environment of banana plantation areas in the North Atlantic Zone of Costa Rica. Environmental Toxicology and Chemistry 19: 1942-1950.

28. Liu Z, Zhang H, Tao M, Yang S, Wang L, et al. (2010) Organochlorine pesticides in consumer fish and mollusks of Liaoning province, China: distribution and human exposure implications. Arch Environ Contam Toxicol 59: 444-453.

29. Global Fish Alliance (2010) The Importance of Captured Fisheries in Food Security in Ghana.

30. Health Canada (1996) Provisional Tolerable Dietary Intake (PTDI) Values presently used by Contaminants Toxicology Section. Food Directorate, Ottawa, Ontario, Canada.

31. (1987) Overall evaluations of carcinogenicity: an updating of IARC Monographs volumes 1 to 42. IARC Monogr Eval Carcinog Risks Hum Suppl 7: 1-440.

32. EXTOXNET (2011) Extension Toxicology Network: Pesticide Information Profiles. 